\title{
Criteria for Affordable Housing Performance Measurement: A Review
}

\author{
A.M.J.Esruq-Labin ${ }^{1}$, A.I.Che-Ani ${ }^{2}$, N.M. Tawil ${ }^{3}$, M.N.M. Nawi ${ }^{4}$, M.A.Othuman Mydin $^{5}$ \\ ${ }^{1,2,3}$ Department of Architecture, Faculty of Engineering \& Built Environment,Universiti Kebangsaan \\ Malaysia (UKM), UKM Bangi 43600, Selangor Malaysia \\ ${ }^{4}$ School of Technology Management and Logistics, Universiti Utara Malaysia, 06010 Sintok, Kedah, \\ Malaysia \\ ${ }^{5}$ School of Housing, Building and Planning, Universiti Sains Malaysia, 11800, Penang, Malaysia
}

\begin{abstract}
A home is one of the basic human needs, thus a new concept known as Grow Home has risen. This concept was established to encourage more families to buy their own houses. The Grow Home concept is based on the notion of affordable housing. This paper aims to explore a proposal for affordable housing measurement with six assessment components. In other words, this work intends to study factors that can affect affordable housing assessment. In this paper, we investigated the 20 criteria for affordable housing assessment given by Mulliner and Maliene in their study. Then, we rearranged these criteria into five components, and added the Grow Home component. Each component has different criteria. Finally, six affordable housing measurement components are identified, namely, income ratios, loans and accommodations, facilities and services, safety and comfort, quality management, and Grow Home. These components are also considered as main factors that directly affect affordable housing. This study aspires to contribute to existing literature by proposing six assessment components as a measurement of affordable housing.
\end{abstract}

\section{Introduction}

A house is one of the basic human needs; most daily life practices of people occur at home. Four dimensions of a home [1]; the first is social dimension which involves social interactions among family members and people outside the family. The second is activity pattern dimension which is significant in the process of producing local space or the development of a home [2]. The third is material dimension which refers to the physical location of the residence. A residence itself and the material objects inside it can have value for their practical uses or as emotionally attached items [3]. Finally, the role of time is important in understanding and explaining meanings attached to a residence [3], [4]. To satisfy the human need for a home, a diverse range of concepts has risen to make houses more affordable to families and individuals; and one such concept is Grow Home.

Grow Home aims to build houses for sale which can be afforded by low-income families. Grow Home is a slim façade, three-storey townhouse that is 4.3 meter wide, with an area of approximately 92.9 square meters. A buyer purchases a Grow Home with a finished first floor and specifies its layout in advanced. A Grow Home contains a kitchen, a bathroom, and a living area. 
One or more upper floors are left unfinished and bare at the time of purchase. Later, as space requirement of the homeowner increases and his/her financial circumstance improves, the owner can finish construction of the upper floor/s. Given that the main goal of Grow Home is to make houses more affordable for families, the following section explains the meaning of affordable housing [5].

\subsection{What is Affordable Housing?}

Affordable housing is a concept which is used to explain socioeconomic and development environments, and which aims to confirm if housing provided for families can be afforded by each income-earner cluster, that is, low, middle, or high income-earner cluster. Aside from its relationship to different aspects of residences and localities through infrastructure and community facilities, affordable housing is also related to the ability of a family to pay for their house [6].

According to Yang and Shen, affordable housing is a feature of housing facilities which is related to customer ability and the desire to own or buy houses. Furthermore, the aforementioned authors defined affordable housing as a connection between housing and people. Affordable housing reflects spending to purchase a house, which is a choice made by a family between housing and nonhousing-related spending [7].

The concept of affordability has three perspectives, namely, repayment, purchase, and income affordability [8]. Differences among these perspectives are shown in Table 1.

Table 1: Discrimination among affordability perspectives

\begin{tabular}{c|l}
\hline Perspective & \multicolumn{1}{c}{ Discrimination } \\
\hline $\begin{array}{c}\text { Repayment } \\
\text { affordability }\end{array}$ & Studies burden imposed on a household with regard to repaying mortgage \\
\hline $\begin{array}{c}\text { Purchase } \\
\text { affordability }\end{array}$ & $\begin{array}{l}\text { Studies whether a household is capable of borrowing enough funds to purchase } \\
\text { a house }\end{array}$ \\
\hline $\begin{array}{c}\text { Income } \\
\text { affordability }\end{array}$ & Measures ratio of house prices to income \\
\hline
\end{tabular}

Affordable housing is measured for different purposes, such as to describe housing of a typical family, analyze trends, compare different household types, administrate rules defining individuals who can access housing subsidies, as well as for definition, prediction, and selection [9].

Mulliner and Maliene [10] listed 20 criteria with which affordable housing can be assessed comprehensively and sustainably. These criteria were validated by professionals from the United Kingdom. However, in the present study, we developed a proposal to divide these 20 criteria into five affordable housing measurement components, which are explained in the discussion section of this paper.

\section{Methodology}

Secondary data on affordable housing measurements were collected from literature review. Affordable housing and Grow Home were defined through critical review of literature. This paper is based on the 20 criteria for affordable housing assessment provided by Mulliner and Maliene. We rearranged these criteria that indirectly affect affordable housing by examining each of their functions. Subsequently, we adopted the study of Friedman and Cammalleri and considered Grow Home as an affordable housing assessment component. 


\section{Discussions}

As stated earlier, this paper is based mainly on the 20 criteria for affordable housing measurement provided by Mulliner and Maliene, in addition to the 5 criteria of Grow Home given by Friedman and Cammalleri. We summarized the 25 criteria and proposed six affordable housing measurement components, namely, income ratios, loans and accommodations, facilities and services, safety and comfort, quality management, and Grow Home. These components directly affect affordable housing, whereas the 25 criteria have a direct relationship with the six assessment components, and affect affordable housing indirectly.

\subsection{Income ratios}

The component income ratios involve house price in relation to income, and rental cost in relation to income. Various studies discussed the income ratio component. For example, affordable housing is defined as a ratio of property value over the yearly gross income of an individual, with a ratio of 2.5 as the yardstick. In reality, this ratio does not only differ greatly among cities but also among professions; income affordability mainly uses price-income Ratio (PIR) as a measurement. The Final Report published by The Chinese Academy of Social Sciences Institute of Finance and Trade Economics and The Institute of Public Administration (1996) explained that ratios ranging from 2:1 to 7:1 are appropriate, whereas Yuan [11] argued that a ratio between 2:1 and 6:1, depending on the concerned city and location, as appropriate [12].

\subsection{Loans and accommodations}

The component loans and accommodations contain interest rates and mortgage availability, availability of rented accommodation (private and social), availability of low-cost home ownership products, and market-value home ownership products. Lau and Li stated that a certain degree of nonhousing consumption exists, such as for food, clothing, entertainment, transportation, loan repayment for automobiles and personal loans, and so on [13].

The government should design a proposal for people to live in a place of their preference; however, such proposal is not favoured by the government. The designation of strategic market areas, which are often sub-regional in scale, requires that the problem of little affordability should be addressed (by opening land for growth or by providing bonus social housing) through a useful market. Considering that travel time from employment areas to housing search areas is adequate, responding to increasing prices in a village by providing more housing areas in a nearby town is reasonable [14].

\subsection{Facilities and services}

The component facilities and services include access to employment opportunities, public transport services, quality education (i.e., schools), shopping facilities, health services, early childhood care services, leisure facilities, and open green public spaces.

According to the Centre for Transit-Oriented Development and the Centre for Neighbourhood Technology (2006) relationships between housing and location provide a more meaningful measure of affordability. These organizations assessed affordability by investigating cost of housing, and location efficiency by measuring transportation prices related to the place. Current planning and housing policies focus on improving houses with facilities through more extensive functional areas to strengthen aforementioned patterns [15].

Aside from possible dislocation between homes and jobs, the worsening condition of social systems will also have a considerable impact on inhabitants and communities. Moreover, developments often do not respect life cycle of societies, thus damaging relationships between the young and the old, and among family members [16]. 


\subsection{Safety and comfort}

The component safety and comfort include safety of a community, incidence of crime, and presence of environmental problems. The decrease in affordability consequently affects households, such as polarization of cities and social cohesion, workforce market productivity, and economic performance, along with environmental concerns. Environment can be classified into four types, namely, physical, social-cultural, psychological, and physiological [17].

One of the needs of an individual or a family is safety. This need affects housing design; in several countries, a large amount of funds are spent for security purposes. Affordability affects social organization of areas as well as safety at different spatial scales, depending on how it is measured. Easy-to-explain safety results may lead to social consequences that are difficult to justify for governments which aims to deliver social equity within socially stable communities [14], [18].

\subsection{Quality management}

The component quality management involves quality of housing, energy efficiency of housing, waste management, and deprivation in the area. Quality management is related to conditions of the surrounding, such as population density, light, air, energy, waste, and other houses conditions associated with housing. Quality management is influenced by different variables such as engineering practices, social environment, and behavior of the residents. Furthermore, quality management respects the relationship between the function of a place and human needs [14],[34] and [35].

\subsection{Grow Home}

The component Grow Home includes land properties such as size, location and price, number of workers needed to build the house, Grow Home options, unfinished levels, and new spaces that have being added after the household bought the house. Grow Home becomes affordable in several ways; for example, by reducing costs of land when Grow Home units are built on small lots or by reducing per unit hard infrastructure costs by up to $60 \%$ when a small lot size and high area density are used, compared with single houses on regular lots. Furthermore, a small building area decreases the number of workers needed to construct a house.

Different options are available to homeowners in customizing their Grow Home unit, thus allowing them to make trade-offs between amenities and their budget. However, each unfinished floor in a Grow Home unit decreases building prices. Finally, a Grow Home unit has one-third the area of exterior walls and one-half the roof area of a conventional detached house; consequently, $40 \%$ of heating price is reduced in a Grow Home unit compared with a conventional detached house [5].

The price of a Grow Home unit depends on its location and size, whereas the size depends on the household type, that is, whether the household is composed of a young couple with or without children, a single parent, or a single individual.

Grow Home units are affordable to very low-income households, considering that monthly payments can be less than the rent that a household will pay, whether in urban or suburban areas. The dense mass of a Grow Home unit makes it ideal for infill and small lot applications; moreover, it can also be built as a stand-alone house in new subdivisions [5]. Table 2 summarizes participation of the researchers in affordable housing measurement components and the Grow Home component, which are collected from related literature. 
Table 2: Affordable housing measurement components

\begin{tabular}{lll}
\hline Component & Sub-Component & Author \\
\hline Income ratios & House price to income ratio & {$[19],[20],[35]$ and [8] } \\
& Rental cost to income ratio & {$[19],[28]$ and [20] } \\
\hline Loans and & Interest rates and mortgage availability & {$[17]$ and [21] } \\
accommodations & & \\
& Availability of rented accommodation & {$[22],[23],[24]$ and [29] } \\
& Availability of low cost home ownership & {$[22],[23]$ and [24] } \\
& products & \\
& Availability of market value home ownership & {$[22],[23]$ and [24] } \\
& products & \\
\hline Facilities and & Access to employment. & {$[23],[24]$ and [25] } \\
services & Access to public transport services. & {$[19],[23],[24]$} \\
& Access to good quality education (school) & {$[19],[23]$ and [25] } \\
& Access to shopping facilities & {$[23]$ and[26] } \\
& Access to health services & {$[19],[23]$ and [26] } \\
& Access to early years child care services & {$[23],[30],[31]$ andnd [32] } \\
& Access to leisure facilities & {$[23]$ and [26] } \\
& Access to open green public spaces & {$[19],[22][23],[24]$ and [26] } \\
\hline Safety and & Safety- incidence of crime & {$[22],[23]$ and [24] } \\
comfort & Presence of environmental problems & {$[22]$ and[24] } \\
\hline Quality & Quality of housing & {$[22]$ and [24] } \\
management & Energy efficiency of housing & {$[22]$ and [24] } \\
& Waste management & {$[22],[23]$ and [24] } \\
& Deprivation in area & {$[27]$ and [33] } \\
\hline Grow Home & Land properties & {$[5]$} \\
\hline & New spaces & \\
\hline
\end{tabular}

\section{Conclusions}

This study rearranged the 20 criteria provided by Mulliner and Maliene in their study into five components. The latter could be used as affordable housing assessment components, and thus, could contribute to literature on this field. Moreover, the Grow Home component, which is a new concept that considerably affects affordable housing, was included. In conclusion, six affordable housing measurement components were identified, namely, income ratios, loans and accommodations, facilities and services, safety and comfort, quality management, and Grow Home. Grow Home issues could likewise be used as a cost-saving options to make housing more affordable. These issues are related with house quality, options (outline) and size, and land properties, such as location and price. A lower land price and a smaller house size consequently reduce the number of workers required to construct a house, and thus, decreases house price as well. As a result, the house will be more affordable for prospective buyers. This paper complements previous studies with a strategic view in rearranging affordable housing assessment.

\section{References}

1. Semeraro P. and Fregonara, E., 2013. The impact of house characteristics on the bargaining outcome. Journal of European Real Estate Research, 6 (3): 262 - 278.

2. Olewnik, A. and Lewis K., 2008. Limitations of the House of Quality to provide quantitative design information. International Journal of Quality \& Reliability Management, 25 (2)

3. Mallett, S., 2004. Understanding home: a critical review of the literature. The sociological review, 52 (1), 62-89. 
4. Tenório, R. and Pedrini, A., 2002. Sustainable house design: Fernando de Noronha-Brazil, Environmental Management and Health, 13 (4): 330 - 338.

5. Friedman A., 2001. Grow Home. McGill-Queen's Press - MQUP.

6. Tawil, N. M., Yusoff, Y. M., CheAni, A. I., Abdullah, N. A. G., and Surat, M., 2012. A Study of Management Corporation Financial in High Rise Residential with Correlation of Management Fund and Facilities Provided. International Business Management, 6 (3), 304-307.

7. Yang, Z., and Shen, Y., 2008. The affordability of owner occupied housing in Beijing. Journal of Housing and the Built Environment, 23 (4), 317-335.

8. Murdie, R. A., 2003. Housing affordability and Toronto's rental market: perspectives from the housing careers of Jamaican, Polish and Somali Newcomers. Housing, Theory and Society, 20 (4), 183-196.

9. Gan, Q. and Hill, R. J., 2009. Measuring housing affordability: looking beyond the median. Journal of Housing economics, 18 (2), 115-125.

10. Mulliner, E., and Maliene, V., 2012. What Attributes Determine Housing Affordability?. Safety (low crime rate), 6 (4.5), 2-1.

11. Yuan, X. L. and Zuo, J., 2011. Pricing and affordability of renewable energy in China-A case study of Shandong Province. Renewable Energy, 36(3), 1111-1117.

12. Chen, J., Hao, Q. and Stephens, M., 2010. Assessing housing affordability in post-reform China: a case study of Shanghai. Housing Studies, 25 (6), 877-901.

13. Lau, K. M. and Li, S. M., 2006. Commercial housing affordability in Beijing, 19922002. Habitat International, 30 (3), 614-627.

14. Gallent, N. and Robinson, S., 2011. Local perspectives on rural housing affordability and implications for the localism agenda in England. Journal of Rural Studies, 27 (3), 297-307.

15. Hoggart, K. and Henderson, S., 2005. Excluding exceptions: Housing non-affordability and the oppression of environmental sustainability?. Journal of Rural Studies, 21 (2), 181-196.

16. Cuba, L. and Hummon, D. M., 1993. A place to call home: Identification with dwelling, community, and region. The sociological quarterly, 34 (1), 111-131.

17. Lawson, J., Berry, M., Milligan, V. and Yates, J., 2009. Facilitating investment in affordable housing-towards an Australian model. Housing Finance International, 24 (1), 18-26.

18. Sherstobitov, L. V., 2013. The Quality of City Environment: Description Model, Measurement, Example of Model Us. World Applied Sciences Journal, 27: 336-34.

19. Treasury, H. M. Department for Business, Enterprise and Regulatory Reform (BERR) and Communities and Local Government (CLG), 2007. Review of Sub-National Economic Development and Regeneration London HMT.

20. Whitehead, K. A., Langer, R. and Anderson, D. G., 2009. Knocking down barriers: advances in siRNA delivery. Nature reviews Drug discovery, 8 (2), 129-138.

21. Kondybayeva, S. K. and Ishuov Z. S., 2013. The Effect of Monetary Policy on Real House Price Growth in the Republic of Kazakhstan: A Vector Autoregression Analysis. World Applied Sciences Journal, 22 (10): 1384-1394.

22. Maliene, V. and Malys, N., 2009. High-quality housing-A key issue in delivering sustainable communities. Building and Environment, 44 (2), 426-430.

23. Treasury, H. M., 2007. ODPM (2005) The Government Response to Kate Barker's Review of Housing Supply.

24. Winston, N., 2010. Regeneration for sustainable communities? Barriers to implementing sustainable housing in urban areas. Sustainable Development,18 (6), 319-330.

25. Coulson, N. E. and Fisher, L. M., 2009. Housing tenure and labor market impacts: The search goes on. Journal of Urban Economics, 65(3), 252-264.

26. Zhu, H., 2006. The structure of housing finance markets and house prices in Asia. BIS Quarterly Review, 12, 55-69.

27. Naik, V. D. and Gupta, P. C., 1996. A note on estimation of mean with known population proportion of an auxiliary character. Jour. Ind. Soc. Agr. Stat, 48 (2), 151-158. 
28. Abdoli, M. Shurvarzi M. and Farokha A. D., 2012. Economic Value Added vs. Accounting Residual Income; Which One Is a Better Criterion for Measurement of Created Shareholders Value? World Applied Sciences Journal, 17 (7): 874-881.

29. Kryukova, E. M. Novikova, N. G. Zikirova S. S. and Podsevalova E. N., 2014. Financing of Social Housing Stock in Russia and Abroad. World Applied Sciences Journal, 30 (12): 17461748.

30. Olaleye, O. Florence, O. and Omotayo, K.A., 2009. Assessment of Quality in Early Childhood Education in Ekiti State Nigeri. World Applied Sciences Journal, 7 (5): 683-688.

31. Ulyanova, O., 2013. A Research Methodology of the Housing Crisis in Modern Russia. World Applied Sciences Journal, 25 (8), 1209-1216. ISSN 1818-4952.

32. Ghodrati, N. Samari, M. and Shafiei M. W. M., 2012. Investigation on Government Financial Incentives tonSimulate Green Homes Purchase. World Applied Sciences Journal, 20 (6), 832841.

33. Molchanov, V. M. and Blagova, M. V., 2013. Architectural-Design Commercial Dwelling Models on a Social-Functional Basis (Through the Example of Rostov-On-Don). World Applied Sciences Journal, 27(9), 1194-1200.

34. Kalhor, M. A. Esmailpour, H. and Ahmadi, F., 2013. Evaluation the Performance of the Mehr Housing Project in Iran (Case Study Saqez City). Middle-East Journal of Scientific Research, 15 (5), 707-711. ISSN 1990-9233.

35. Jiboy, A. D., 2011. Evaluating Public Housing Performance: Providing a Basis for Residential Quality Improvement in Nigeria. Middle-East Journal of Scientific Research, 9 (2), 225-232. ISSN 1990-9233. 